\title{
PENANAMAN NILAI-NILAI ISLAM DALAM KEGIATAN SEBELUM BELAJAR SISWA DI SMP PGII 1 BANDUNG
}

\author{
Muhamad Imam Pamungkas \\ Program Studi Pendidikan Agama Islam, Fakultas Tarbiyah dan Keguruan Unisba \\ Jl. Ranggagading No. 8, 40116, Bandung, Indonesia \\ Email: m.imampamungkas@yahoo.com \\ DOI: 10.29313 /tjpi.v6i1.2374 \\ Accepted: April 12th, 2017. Approved: July 20th, 2017. Published: July 20th, 2017
}

\begin{abstract}
This study aimed to describe the implantation Islamic values in the activity of Prior Learning Students in Junior High School of PGII 1 Bandung. The problems discussed in this study are the application of implantation Islamic values in the activity of Prior Learning Students in Junior High School of PGII 1 Bandung. The method used is qualitative, the main instruments are the interview and observation. Data analysis performed in this study is descriptive and analytical. The results showed that the implantation Islamic values in the activity of Prior Learning Students in Junior High School of PGII 1 Bandung has been carried out and implemented through prior learning which includes discipline, reciting of Asmaul Husna, reciting of Qur'an and prayer after it, singing of Indonesia Raya, reading stories or hadith, reading books, dan reciting salaam to the teacher.
\end{abstract}

Keywords: The Implantation of $V$ alues, and Prior Learning.

ABSTRAK

Penelitian ini bertujuan untuk mendeskripsikan penanaman nilai-nilai Islam dalam kegiatan sebelum belajar siswa SMP PGII 1 Bandung. Permasalahan yang dibahas dalam penelitian ini adalah aplikasi penanaman nilai-nilai Islam dalam kegiatan sebelum belajar siswa SMP PGII 1 Bandung. Metode yang digunakan adalah kualitatif, dengan instrumen utamanya adalah wawancara dan observasi. Analisis data yang dilakukan dalam penelitian ini adalah deskriptif analitik. Hasil penelitian menunjukkan bahwa penanaman nilai-nilai Islam di SMP PGII 1 Bandung tersebut telah dilaksanakan dan diterapkan melalui kegiatan sebelum belajar yang meliputi kedisiplinan, membaca asmaul husna, membaca al-Qur'an dan doa setelahnya, menyanyikan lagu Indonesia Raya, membacakan kisah-kisah atau hadits, membaca buku, dan mengucapkan salam kepada guru.

Kata kunci: Penanaman Nilai, dan, Sebelum Belajar. 


\section{PENDAHULUAN}

Pendidikan agama saat ini menjadi pertanyaan banyak orang. Hal tersebut muncul manakala banyak problematika dan permasalahan yang terjadi di sekitar kita yang berada pada aspek agama (keagamaan). Sebut saja dengan adanya degradasi akhlak, tawuran antar pelajar, sampai kepada kasus negara seperti korupsi yang seolah-olah tak ada ujungnya. Padahalnya, harusnya dengan adanya pendidikan agama dapat membendung dan membentengi hal tersebut di atas.

Apabila kita lihat dari sejarah, pendidikan agama mulai dari bangsa Indonesia merdeka tahun 1945 telah diajarkan di sekolah-sekolah negeri. Pada masa kabinet RI pertama tahun 1945,

Menteri Pendidikan, Pengajaran dan Kebudayaan yang pertama Ki Hajar Dewantara telah mengirimkan surat edaran ke daerah-daerah yang isinya menyatakan bahwa pelajaran budi pekerti yang telah ada pada masa penjajahan Jepang tetap diperkenankan dan diganti namanya menjadi pelajaran Agama (Muhammad Kholid Fathoni, 2005: 37). Pada saat itu, pendidikan agama belum menjadi suatu kewajiban untukdiajarkan pada sekolah-sekolah umum. Akan tetapi keberadaannya bersifat sukarela, dan tidak menjadi penentu kenaikan/kelulusan peserta didik.

Muhammad Kholid Fathoni (2005:

37) menjelaskan bahwa pendidikan agama berstatus sebagai mata pelajaran pokok di sekolah-sekolah umum mulai SD sampai dengan Perguruan Tinggi berdasarkan TAP MPRS nomor XXVII/MPRS/1966 Bab I Pasal I yang berbunyi:'Menetapkan pendidikan agama menjadi mata pelajaran di sekolah-sekolah mulai dari Sekolah Dasar sampai dengan Universitas-Universitas Negeri". Peraturan ini keluar dengan tanpa protes, setelah penumpasan PKI.

Pelaksanaan pendidikan agama pada umumnya, serta pendidikan agama Islam pada khususnya di sekolah-sekolah umum tersebut semakin kokoh dengan terbitnya perundang-undangan selanjutnya, hingga lahirnya UU nomor 20 tahun 2003 tentang Sistem Pendidikan Nasional (SISDIKNAS) yang lebih menjamin pemenuhan pendidikan agama kepada peserta didik. Kemudian diikuti dengan lahirnya peraturan-peraturan selanjutnya sampai dengan terbitnya Peraturan Menteri Agama RI Nomor 16 Tahun 2010 tentang Pengelolaan Pendidikan Agama Pada Sekolah.

Melihat keberadaan dalam sistem pendidikan nasional, maka pendidikan agama semakin kuat posisinya. Tentunya setelah mengalami masa pergulatan yang sangat panjang. Dan dilihat dari aspek tersebut, tentunya pendidikan agama tersebut telah menunjukkan hasil yang signifikan. Akan tetapi dalam kenyataannya di sekitar kita (kehidupan sehari-hari), banyak sekali permasalahan atau problematika yang muncul sehingga berakibat tidak maksimalnya Pendidikan Agama Islam (PAI) di sekolah, baik di tingkat dasar (SD) atau pun menengah (SMP/SMA).

Pendidikan Agama Islam yang sudah ada dan menjadi mata pelajaran di sekolah tersebut harus menghasilkan suatu nilai (Islam) yang diimplementasikan dalam setiap aspek kehidupan, terutama di lingkungan sekolah. Dengan nilai tersebut, maka Pendidikan Agama Islam yang muncul tidak hanya bersifat teoretis, akan tetapi secara praktis juga. Saat ini, nilai-nilai dari agama (Islam) harus dapat dirasakan bukan hanya dari aspek kognitif saja, melainkan dari aspek afektif, dan juga psikomotonya.

Penanaman nilai-nilai Islam dalam suatu pendidikan tersebut harus mudah dipahami sehingga para siswa atau peserta didik dapat mengaplikasikannya dalam kehidupan sehari-hari. Aplikasi dari nilainilai Islam tersebut setidaknya terimplementasikan di lingkungan terdekat para peserta didik, seperti di sekolah atau pun di keluarga. Lebih jauh lagi, mereka dapat mewujudkannya di mana pun mereka 
berada sebagai implementasi dari Khalifatun fil Ardhi (menjadi khalifah di muka bumi).

Untuk memahami nilai suatu pendidikan Islam, Muhaimin (2004: 29-30) menjabarkannya sebagai berikut: (1) Pendidikan menurut Islam atau Pendidikan Islami, yakni pendidikan yang dipahami dan dikembangkan dari ajaran dan nilai-nilai fundamental yang terkandung dalam sumber dasar Islam, yaitu al-Quran dan Sunnah. Dalam pengertian yang pertama ini, pendidikan Islam dapat berwujud pemikiran dan teori pendidikan yang mendasarkan diri atau dibangun dan dikembangkan dari sumber-sumber dasar tersebut. Pendidikan ke-islam-an atau Pendidikan Agama Islam, yakni upaya mendidikan agama Islam atau ajaran Islam atau nilai-nilai Islam agar menjadi way of life (pandangan dan sikap hidup) seseorang. (3) Pendidikan dalam Islam atau proses dan praktik penyelenggaraan pendidikan yang berlangsung dan berkembang dalam sejarah umat Islam. Dalam arti prosesbertumbuhkembangnya Islam dan umatnya,baik Islam sebagai agama, ajaran, maupun sistem budaya dan peradaban sejak zaman Nabi Muhammad Saw sampai sekarang.

Ada pun Zuhairini dan Abdul Ghafir (2004: 48) berpendapat bahwa nilai-nilai Islam yang terkandung dalam Pendidikan Agama Islam di sekolah tersebut harus mencakup ruang lingkup:(1) Ilmu Tauhid/Keimanan, (2) Ilmu Fiqih, (3) AlQur'an, (4) Al-Hadist, (5) Akhlak dan (6) Tarikh Islam. Apabila dijabarkan kandungan nilai-nilai Pendidikan Agama Islam (PAI) tersebut adalah sebagai berikut:

Pengajaran al-Quran adalah pengajaran yang bertujuan agar siswa dapat membaca dan menulis Al-Quran (BTAQ) serta mengerti arti kandungan yang terdapat di setiap ayat-ayat Al-Quran. Namun dalam prakteknya hanya ayat-ayat tertentu yang di masukkan dalam materi Pendidikan Agama Islam yang disesuaikan dengan tingkat pendidikannya.
Pengajaran al-Hadits adalah pengajaran yang bertujuan agar siswa dapat membaca dan menulis al-Hadits serta mengerti arti kandungan yang terdapat di dalam al-Hadits.Akan tetapi dalam prakteknya hanya hadits-hadits tertentu yang di masukkan dalam materi Pendidikan Agama Islam yang disesuaikan dengan tingkat pendidikannya.

Pengajaran keimanan merupakan proses belajar mengajar tentang aspek kepercayaan dan keyakinan. Dalam hal ini tentunya kepercayaan dan keyakinan menurut ajaran dan syariat Islam. Inti dari pengajaran ini adalah tentang rukun Iman.

Pengajaran akhlak adalah bentuk pengajaran yang mengarah pada pembentukan jiwa, cara bersikap individu pada kehidupannya. Pengajaran ini berarti proses belajar mengajar dalam mencapai tujuan supaya yang diajarkan memiliki akhlak mulia.

Pengajaran fiqih adalah pengajaran yang isinya menyampaikan materi tentang segala bentuk-bentuk hukum Islam yang bersumber pada al-Quran, Hadits/Sunnah, dan dalil-dalil syar'i yang lain. Tujuan dari pengajaran materi ini adalah agar siswa mengetahui dan mengerti tentang hukumhukum Islam dan melaksanakannya dalam kehidupan sehari-hari.

Tujuan pengajaran dari sejarah Islam ini adalah agar siswa dapat mengetahui tentang pertumbuhan dan perkembangan agama Islam dari dulu sampai sekarang, sehingga siswa dapat mengenal dan mencintai agama Islam lebih dalam lagi.

Selain dari ruang lingkup dalam Pendidikan Agama Islam tersebut, nilai-nilai Islam tersebut juga harus muncul dalam berbagai bentuk karakter yang tertanam dalam dirinya sehingga membentuk kepribadian seseorang. Samsul Ma'arif (2014: 2) mengatakan bahwa nilai-nilai yang perlu ditanamkan dalam diri peserta didik mencakup nilai-nilai yang sesuai dengan budaya bangsa Indonesia, misalnya nilai-nilai kesopanan, toleransi, kehormatan, 
kejujuran, bertanggung jawab, bekerjasama, beribadah, jujur dan lain sebagainya.

Nilai-nilai Islam dan peradaban tidak dapat dipisahkan dengan kelahiran Islam itu sendiri. Maka dari itu lembaga-lembaga pendidikan memiliki tugas selain mengembangkan perolehan pengalaman, lembaga pendidikan harus mampu mengupayakan perolehan pengalaman generasi terdahulu melalui transfer tradisi. Islam mengemban tugas menghidupkan kembali tradisi, konsep keagamaan, dan mewariskan ilmu-ilmu yang diperoleh dari kitab-kitab lama ke generasi selanjutnya (Lukis Alam, 2016: 110)

Dengan berbagai latarbelakang tersebut, peneliti tertarik akan suatu pembahasan tentang sebuah lembaga pendidikan atau satuan pendidikan yang menerapkan nilai-nilai Islam dalam proses pembelajarannya. Dari sekian banyak satuan pendidikan yang ada di kota Bandung, peneliti tertarik mengambil studi kasus di SMP PGII 1 Bandung, terkhusus lagi ketertarikan dengan adanya aktivitas sebelum Kegiatan Belajar Mengajar (KBM) dimulai yang menurut peneliti ada keterkaitan dengan judul penelitian yang akan dibahas tersebut.

\section{METODOLOGI PENELITIAN}

Penelitian ini menggunakan metode deskriptif analitik dengan tipe studi kasus. Ada pun jenis data yang digunakan dalam penelitian ini bersifat kualitatif, yaitu suatu penelitian yang menghasilkan data deskriptif berupa data-data tertulis atau lisan dari orang-orang dan perilaku yang dapat diamati (Lexy J Moleong, 2011: 4).Sumber data yang digunakan untuk penelitian ini adalah data primer dan sekunder. Sumber data primer dalam penelitian ini adalah para pengambil kebijakan di SMP PGII 1 Bandung, guruguru, dan para siswanya. Sedangkan sumber data sekunder adalah dokumentasidan data lainnya yang berkaitan dengan aktivitas sebelum Kegiatan Belajar Mengajar (KBM). Teknik pengumpulan data dilakukan dengan cara observasi, interview atau wawancara, dokumentasi, dan kepustakaan. Kemudian, analisis data yang dilakukan dalam penelitian ini adalah deskriptif analitik.Sedangkan pelaksanaan dari penelitian ini dilakukan pada tahun 2017.

\section{PEMBAHASAN}

Sebelum pada pembahasan, maka peneliti akan mengkaji beberapa istilah yang terkait dengan penelitian ini sebagai bagian dari landasan teori yang dijadikan acuan dalam penelitian tersebut.

Yang pertama adalah terkait dengan istilah penanaman nilai. Penanaman nilainilai keagamaan merupakan segala usaha memelihara dan mengembangkan fitrah manusia serta sumber daya insani yang ada padanya menuju terbentuknya manusia seutuhnya (insan kamil) sesuai dengan norma Islam (Yana, 2015: 20)

Dalam judul penelitian, secara eksplisit peneliti menuliskan "Penanaman Nilai-nilai Islam....", yang pada intinya hampir sama secara makna dengan definisi yang telah termaktub pada pernyataan sebelumnya, yaitu kata "keagamaan". Kata "keagamaan" tersebut tentunya dihubungkan dengan agama Islam yang menjadi sumber utama rujukan dalam penelitian tersebut.

Namun demikian, akan kita bahas lebih lanjut lagi terkait dengan nilai. Yana Dian Ika Pratiwi (2015: 22) menyebutkan bahwa nilai adalah suatu perangkat keyakinan ataupun perasaan yang diyakini sebagai suatu identitas yang memberikan corak yang khusus kepada pola pemikiran, perasaan, keterikatan, maupun perilaku. Nilai juga berarti keyakinan yang membuat seseorang bertindak atas dasar pilihannya.

Sedikit perbedaan mengenai definisi nilai sebagaimana yang dijelaskan Samsul Ma'arif (2014: 3) bahwa nilai adalah harga, kualitas, atau sesuatu yang dianggap berharga dan menjadi tujuan yang hendak dicapai. 
Light, Keller, \& Calhoun (1989: 81) memberikan batasan nilai sebagai berikut: "Value is general idea that people share about what is good or bad, desirable or undesirable. Value transcends any one particular situation. ... Value people hold tends to color their overall way of life. (Nilai merupakan gagasan umum yang orang-orang sepakati tentang sesuatu yang baik atau buruk, yang diharapkan atau yang tidak diharapkan. Nilai melampaui situasi yang khusus. ... nilai yang dipegang masyarakat cenderung mewarnai keseluruhan cara hidup mereka).

Nilai bukan saja dijadikan rujukan untuk bersikap dan berbuat dalam masyarakat, akan tetapi dijadikan pula sebagai ukuran benar tidaknya suatu fenomena perbuatan dalam masyarakat itu sendiri. Apabila ada suatu fenomena sosial yang bertentangan dengan sistem nilai yang dianut oleh masyarakat, maka perbuatan tersebut dinyatakan bertentangan dengan sistem nilai yang dianut masyarakat, dan akan mendapatkan penolakan dari masyarakat tersebut (Ali Muhtadi, 2006: 3)

Belajar merupakan suatu aktivitas yang sudah tidak asing lagi bagi setiap orang. Sejak usia dini hingga dewasa, belajar senantiasa mengikuti kehidupan dari manusia itu sendiri. Dalam Islam, belajar dikaitkan dengan istilah menuntut ilmu (tholabul ilmi), yang aplikasinya tersebut harus diterapkan sejak dari buaian hingga liang kubur (uthlubul ilma minal mabdi ila al-lahdi). Terlebih lagi apabila kita merujuk pada hadits Rasulullah Saw bahwa belajar atau menuntut ilmu itu wajib hukumnya, baik bagi muslim laki-laki atau pun perempuan.

Banyak sekali rumusan dan definisi dari belajar, akan tetapi peneliti akan membatasinya berdasarkan pendapat para ahli. M. Suardi (2015: 9-10) mengungkapkan beberapa pandangan mengenai belajar dari para ahli sebagai berikut:

Pertama, W.H. Buston memandang belajar sebagai perubahan tingkah laku pada diri individu dengan lingkungannya. Buston berpendapat bahwa unsur utama dalam belajar adalah terjadinya perubahan pada seseorang. Perubahan tersebut menyangkut aspek kepribadian yang tercermin dari perubahan yang bersangkutan, yang tentu juga bersamaan dengan interaksinya dengan linkungan dimana ia berada.

Kedua, J. Neweg melihat dari dimensi yang dapat berbeda. Dia menganggap bahwa belajar adalah suatu proses dimana perilaku seseorang mengalami perubahan sebagai akibat pengalaman buruk. Paling tidak, ada tiga unsur yang terkadang pemberian Neweg. Pertama, dia melihat belajar itu sebagai suatu proses yang terjadi dalam diri seseorang. Sebagai suatu proses berarti ada tahap-tahap yang dilalui seseorang. Unsur kedua adalah pengalaman. Belajar itu baru akan terjadi kalau proses seperti yang disebutkan terdahulu dialami sendiri oleh yang bersangkutan. Belajar itu pada dasarnya mengalami, learning by experience. Unsur ketiga ialah perubahan perilaku. Muara dari proses yang dialami seseorang itu adalah terjadinya perubahan perilaku pada yang bersangkutan. Ketiga, Skiner berpendapat agak lain, dia berpandangan bahwa belajar adalah suatu perilaku. Pada seseorang yang belajar maka responnya akan menjadi lebih baik. Sebaliknya, apabila tidak belajar, responnya menjadi menurun.

Keempat, Sagne berpendapat bahwa belajar adalah proses kognitif yang mengubah sifat stimulasi lingkungan, melewati pengolahan informasi menjadi kopabilitas baru, berupa keterampilan, pengetahuan, sikap, dan nilai. Dia melihat, bahwa timbulnya kapabilitas baru itu sebagai hasil dari stimulasi yang berasal dari lingkungan dan proses kognitif yang dilakukan oleh individu.

\section{Profil SMP PGII 1 Bandung}

Sekolah ini beralamatkan di Jl. Panatayuda No. 2 yang dipimpin oleh Drs. Mochamad Rachman sebagai kepala sekolah yang ke-11 sejak berdirinya sekolah ini pada tahun 1969. Sekolah ini memiliki visi menjadi sekolah Islam yang unggul, yang 
kemudian dijabarkan dalam beberapa misinya, yaitu: (1) menjadikan nilai-nilai ajaran Islam sebagai ruh dan dasar bagi pengelolaan pendidikan (Islam Disiplin Ilmu), (2) membangun model kepemimpinan dan organisasi yang aspiratif, inspiratif, transpormatif, dan partisipatif. (3) mengembangkan model kurikulum yang seimbang, adaptif, kreatif, inovatif, mendasar dan menyeluruh sesuai dengan kebutuhan dan perkembangan zaman. (4) menggali dan mengembangkan seluruh potensi siswa sesuai dengan kebutuhan dan pemenuhan kapasitasnya menjadi pribadi yang cerdas, mandiri, dan berbakti kepada kedua orang tuanya. (5) membangun kemitraan yang kondusif, partisipatif, dan prestatif dengan pemangku pendidikan (Stakeholde).

Sekolah yang memiliki akreditasi "A" ini memiliki tujuan menghasilkan anak yang sholeh, cerdas, dan Islami dengan mottonya "Menjadi Sekolah Pilihan Utama dan Pertama". Sekolah ini senantiasa memiliki peserta didik yang banyak karena daya tampung yang disediakan tiap tahunnya pun cukup banyak, yaitu sebanyak 8 kelas dengan jumlah tiap kelasnya 36 orang. SMP PGII 1 Bandung menyelenggarakan Kegiatan Belajar Mengajar (KBM) dari pkl. 06.45 15.00, sehingga peserta didik dapat dipantau ibadah sholat dhuhur dan asharnya karena masih berada di lingkungan sekolah.

Sekolah yang didirikan di atas tanah seluas $658 \mathrm{~m}^{2}$ (milik yayasan PGII) dan 3287 $\mathrm{m}^{2}$ (milik pemerintah kota Bandung) memiliki kriteria jaminan mutu lulusan, yaitu mutu lulusan berdasarkan Standar Kelulusan Satuan Pendidikan, yang terdiri dari: (1) mengamalkan ajaran agama yang dianut, (2) memahami kekurangan dan kelebihan diri, (3) menunjukkan sikap percaya diri, (4) mematuhi aturan-aturan sosial yang berlaku, (5) menghargai keberagamaan, (6) mencari dan menerapkan informasi secara logis, kritis, dan inovatif, (7) menunjukkan kemampuan belajar mandiri, (8) menunjukkan kemampuan mengalisis masalah, (9) mendeskripsikan gejala alam dan sosial, (10) memanfaatkan lingkungan secara bertanggung jawab, (11) menerapkan nilai-nilai kebersamaan dalam masyarakat, (12) menghargai karya seni dan budaya, (13) menghargai tugas pekerjaan, (14) menerapkan hidup bersih dan sehat, (15) memanfaatkan waktu luang, (16) berkomunikasi secara efektif, (17) memahami hak dan kewajiban, (18) menghargai perbedaan pendapat, (18) menunjukkan kegemaran membaca dan menulis, (19) menunjukkan keterampilan menyimak, berbicara, dan membaca, (20) menguasai pengetahuan untuk mengikuti pendidikan.

Ada pun kurikulum yang menjadi kekhasan di SMP PGII 1 Bandung adalah: (1) beraqidah mantap dan taat beribadah, khususnya sholat fardhu lima waktu, (2) terampil membaca al-Qur'an, (3) hapal 15 surat Juz'amma, (4) hapal 5 ayat pilihan, (5) hapal 10 hadits, (6) hapal 10 doa pilihan, (7) hapal dzikir asmaul husna, (8) Kriteria Ketuntasan Minimal (KKM) rata-rata 7,50, (9) terampil mengoperasikan komputer program aplikasi MS Word - Excel Powerpoint, dan lain-lain.

Selain yang tersebut di atas, SMP PGII 1 Bandung pun memiliki 4 (empat) program ungggulan, yaitu; Pertama, Potensi Ruhaniah, Memantapkan keyakinan dan komitmen kepada Allah Swt, dengan cara: Sholat dhuhur dan ashar berjama'ah, Dzikir asmaul husna, Muhasabah (doa bersama), Tadarus al-Qur'an, Pengajian Kelas, Wisata rohani

Kedua, Potensi Emosi, Memantapkan komitmen disiplin, rendah hati dan peduli, dengan cara: Dzikir, Wisata Rohani, Semarak Infaq, Jelajah Masjid, Ta'jil on The Road, Bakti Sosial (Baksos).

Ketiga, Potensi Akal. Memantapkan komitmen berpikir kritis, kreatif, inovatif, dan prestatif, dengan cara: Training Motivasi, Tambahan pelajaran, Kelas intensif, Klinik matematika, Outbound dan Eks-day, Olimpiade.

Keempat, Potensi Raga. Memantapkan komitmen hidup sehat, bugar 
dan bersih dengan cara: Observasi lingkungan hidup, Jum'at bersih, Penghijauan, K3 Kelas, Penyuluhan kesehatan, dan Turnamen Futsal antar kelas.

Adapun Jadwal KBM yang dilaksanakan di SMP PGII 1 dapat dilihat dalam tabel berikut:

Tabel 1. Jadwal Kegiatan Belajar Mengajar Hari Senin

\begin{tabular}{ccl}
\hline $\begin{array}{c}\text { Jam } \\
\text { Ke- }\end{array}$ & Waktu & \multicolumn{1}{c}{ Keterangan } \\
\hline 1 & $06.45-08.25$ & $\begin{array}{l}\text { Upacara/Dhuha } \\
\text { /Kewalikelasan }\end{array}$ \\
\hline 2 & $08.25-09.05$ & KBM \\
\hline 3 & $09.05-09.45$ & KBM \\
\hline & $09.45-10.15$ & Istirahat \\
\hline 4 & $10.15-10.55$ & KBM \\
\hline 5 & $10.55-11.35$ & KBM \\
\hline 6 & $11.35-12.15$ & KBM \\
\hline 7 & $12.15-12.55$ & KBM \\
\hline & $12.55-13.40$ & Istirahat + Sholat \\
\hline 8 & $13.40-14.20$ & KBM \\
\hline 9 & $14.20-15.00$ & KBM \\
\hline
\end{tabular}

Tabel 2. Jadwal Kegiatan Belajar Mengajar Hari Selasa Sampai Kamis

\begin{tabular}{ccl}
\hline Jam Ke- & Waktu & \multicolumn{1}{c}{ Keterangan } \\
\hline 1 & $06.45-07.45$ & Mengaji + KBM \\
\hline 2 & $07.45-08.25$ & KBM \\
\hline 3 & $08.25-09.05$ & KBM \\
\hline 4 & $09.05-09.45$ & KBM \\
\hline & $09.45-10.15$ & Istirahat \\
\hline 5 & $10.15-10.55$ & KBM \\
\hline 6 & $10.55-11.35$ & KBM \\
\hline 7 & $11.35-12.15$ & KBM \\
\hline 8 & $12.15-12.55$ & Istirahat + Sholat \\
\hline & $12.55-13.40$ & Istirahat + Sholat \\
\hline & &
\end{tabular}

\begin{tabular}{clll}
\hline 9 & $14 . .40 \quad-$ & $\mathrm{KBM}$ \\
& 14.20 & \\
\hline 10 & $14.20-15.00$ & $\mathrm{KBM}$ \\
\hline
\end{tabular}

Tabel 3. Jadwal Kegiatan Belajar Mengajar Hari Jum'at

\begin{tabular}{ccl}
\hline $\begin{array}{c}\text { Jam } \\
\text { Ke- }\end{array}$ & Waktu & \multicolumn{1}{c}{ Keterangan } \\
\hline 1 & $06.45-07.45$ & Mengaji + KBM \\
\hline 2 & $07.45-08.25$ & KBM \\
\hline 3 & $08.25-09.05$ & KBM/Mentoring \\
\hline 4 & $09.05-09.45$ & KBM/Mentoring \\
\hline & $09.45-10.15$ & Istirahat \\
\hline 5 & $10.15-10.50$ & KBM/Mentoring \\
\hline 6 & $10.50-11.25$ & KBM/Mentoring \\
\hline 7 & $11.25-$ & $\begin{array}{l}\text { Sholat } \\
\text { Jum'at/keputrian }\end{array}$ \\
\hline
\end{tabular}

\section{Analisis Penanaman Nilai-nilai Islam dalam Kegiatan Sebelum Belajar}

Sesuai dengan batasan penelitian, maka pembahasan akan difokuskan pada kegiatan atau aktivitas siswa (peserta didik) sebelum belajar atau pembelajaran dimulai.

(1) Penyambutan siswa (peserta didik) oleh Guru di gerbang sekolah

Sebagaimana telah terlampir dalam tabel jadwal KBM harian bahwa semua siswa diharuskan sudah masuk dan datang ke sekolah pada pukul 06.45. Maka dari itu, para guru biasanya bergantian menjaga dan menyambut para siswa di gerbang pintu masuk sekolah. Dengan adanya agenda tersebut, maka guru dapat langsung mengarahkan siswa untuk segera masuk ke kelas apabila mereka sudah sampai pintu masuk sekolah. Kemudian, guru pun dapat mencatat bagi siswa yang datang terlambat, sehingga bagi mereka (para siswa) yang sering datang terlambat akan merasa malu. Dengan demikian siswa akan belajar dan dibiasakan hidup disiplin dan tepat waktu.

Nilai-nilai Islam yang terkandung dalam kegiatan tersebut yang pertama adalah siswa senantiasa diajarkan hidup disiplin dan 
tepat waktu dalam segala di kehidupannya sehari-hari. Islam sangat menjunjung tinggi kedisiplinan dan menghargai waktu. Bahkan, karena pentingnya nilai sebuah waktu, Allah Swt mengabadikan dan bersumpah dalam salah satu firmannya, yaitu $W$ al $A s h r$ (Demi waktu). Yang kedua, Filosofi dan hikmah dari sholat adalah mengajarkan tepat waktu, karena seseorang dianggap tidak sah sholatnya apabila tidak sesuai dengan waktu yang telah ditentukan. Yang ketiga, adalah adanya aspek muraqabah (Merasa diawasi). Dalam Islam, manusia hidup sebagai makhluk Allah Swt yang tugas utamanya adalah beribadah kepada-Nya (Q.S AdzDzariyat: 56). Sedangkan dalam ibadah, setiap muslim harus memiliki jiwa merasa diawasi oleh-Nya. Terlebih lagi Allah Swt pun mengutus malaikat untuk senantiasa mencatat segala amal dan perbuatan manusia, baik yang berupa keburukan atau pun kebaikan.

\section{Membaca Asmaul Husna}

Setelah para siswa berada di kelas masing-masing, maka kegiatan pun berlangsung secara jama'ah atau bersamasama dengan dipimpin oleh guru atau oleh siswa yang sudah dipilih oleh guru sebagai pemimpin. Di setiap kelas, ada seorang guru yang mengawasi jalannya kegiatan tersebut. Guru yang berada di setiap kelas tersebut adalah guru yang akan mengajar pada jam pelajaran pertama. Guru yang bertugas memandu tersebut membaca asmaul husna yang diikuti oleh semua siswa di kelas. Metode tersebut dilakukan melalui pengeras suara yang terintegrasi ke setiap kelas, sehingga dapat terdengar oleh setiap siswa di kelas. Dengan pembacaan asmaul husna secara bersamaan tersebut dan setiap hari, tentunya memudahkan bagi para siswa untuk menghapalkannya. Selain itu dengan membaca dan mengkaji asmaul husna tersebut merupakan bagian dari penggalian nilai-nilai aqidah yang dapat meningkatkan keimanan dan ketakwaan dari para siswa tersebut. Para siswa dapat mengenal Nur
Ilabiah (Cahaya Ketuhanan) melalui asmaul husna yang senantiasa dibacanya setiap hari.

\section{Membaca al-Qur'an}

Setelah selesai membaca dan atau menghapal asmaul husna, aktivitas berikutnya adalah membaca al-Qur'an. Kegiatan ini pun sama dengan yang awal, yaitu guru membimbing melalui pengeras suara yang diikuti oleh para siswa. Kegiatan tersebut serempak diikuti oleh semua siswa terlebih lagi di setiap kelas ada seorang guru yang juga mengawasinya. Namun demikian, ada beberapa hal yang perlu dikaji lagi, tentunya keterkaitan dengan evaluasi mengaji atau baca al-Qur'an yang tidak dapat dilakukan dengan motode jama'i (berbarengan) seperti itu.

Dengan aktivitas tersebut, setidaknya para siswa terbiasa membaca alQur'an setiap hari, setidaknya ketika mereka berada di sekolah sebelum memulai pelajaran.

\section{Membaca doa setelah membaca al- Qur'an}

Selanjutnya adalah aktivitas membaca doa setelah selesai membaca alQur'an. Kegiatan itu pun tetap dipandu dan dibimbing oleh guru melalui pengeras suara yang terintegrasi ke setiap kelas. Berdoa tentunya berharap yang baik, sehingga dengan selesainya membaca al-Qur'an tentunya berharap dapat memperoleh rahmat dan petunjuk sebagai bagian dari keutamaan membaca al-Qur'an tersebut.

Sebagaimana yang diketahui, bahwa dalam membaca al-Qur'an terdapat banyak sekali keutamaannya. Jadi, dengan memperbanyak bergaul dan berinteraksi dengan al-Qur'an tersebut dapat mendekatkan pembacanya dengan segala kebaikan 


\section{Menyanyikan lagu Indonesia Raya}

Kegiatan selanjutnya adalah menyanyikan lagu Kebangsaan Indonesia Raya. Ini dilakukan oleh semua siswa di kelas sambil berdiri dipimpin oleh seorang dirigen dari setiap kelasnya yang maju ke depan kelas. Menyanyikan lagu Indonesia Raya setiap hari tentunya dapat menambah rasa kebangsaan dan nasionalisme para siswa terhadap negaranya, sehingga muncul rasa kebanggaan dan cinta terhadap tanah airnya. Dalam Islam sendiri, mencintai negara merupakan bagian dari keimanan seseorang. Sehingga bagi seorang muslim, maka dia akan berjuang dan berkorban demi bangsa dan negaranya tersebut. Dengan cinta terhadap tanah airnya, para siswa sebagai generasi penerus bangsa diharapkan kelak yang akan membangun bangsa dan negaranya ke arah yang lebih baik.

\section{Menceritakan Kisah Sejarah/Hadits}

Kegiatan setelah menyanyikan lagu Indonesia Raya adalah menceritakan atau membacakan suatu hadits. Jadi, guru yang memandu melalui pusat pengeras suara membacakan atau mengisahkan tentang suatu cerita yang tentunya dapat diambil hikmah dan pelajarannya bagi setiap siswa. Atau terkadang diselingi dengan membacakan sebuah hadits beserta artinya, yang akhirnya sama-sama untuk mencari hikmah dan pelajaran dari hadits tersebut. Dengan harapan, tentunya para siswa dapat menambah wawasan atau ilmu keislamannya yang menjadikan bekal baginya di kemudian hari. Bahkan, terkadang, pada sesi ini guru yang memandu juga sering mengingatkan para siswa untuk senantiasa sholat, terlebih lagi sholat subuh. Pernah juga terjadi, guru yang memandu mengingatkan para siswa yang lupa atau belum melaksanakan sholat subuh untuk segera menuju ke lantai tiga dan melaksanakan sholat subuh disana. Pelajaran yang dapat diambil adalah tentunya para guru mengingatkan bahwa sholat itu penting dan tidak boleh ditinggalkan. Selain dari itu, para guru juga senantiasa mengingatkan untuk shodaqah dan infak. Seiring dengan pengingatan melalui pengeras suara tersebut, biasanya di setiap kelas saat itu juga langsung beredar kotak amal yang harus diisi oleh para siswa.

\section{Literasi atau Membaca Buku}

Kegiatan lainnya yang dilakukan sebelum memulai belajar adalah membaca buku. Kegiatan ini dilakukan sekitar 10 menit dan buku yang dibacanya pun bebas. Bebas dalam artian tidak terikat dengan buku yang dipelajari di sekolah, akan tetapi buku cerita atau novel pun boleh dibaca pada saat itu. Tentunya buku yang dibacanya adalah buku yang membawa kebaikan dan menambah wawasan keilmuan. Membaca merupakan kegiatan yang sangat penting, bahka termasuk ibadah apabila yang dibacanya tersebut membawa kepada kebaikan. Sebagaimana yang kita ketahui bahwa ayat pertama yang diwahyukan Allah Swt kepada Rasulullah Saw melalui perantara malaikat Jibril adalah terkait dengan perintah membaca (Iqra). Untuk kegitan ini langsung dilakukan oleh para siswa di kelasnya masing-masing dengan pengawasan dari guru yang berada di kelasnya masing-masing.

\section{Siswa Mengucapkan Salam Sebelum Belajar Mulai Kepada Guru}

Kegiatan terakhir yang dilakukan para siswa sebelum belajar adalah memberikan atau mengucapkan salam kepada guru masing-masing yang saat itu sedang berada di kelas untuk mengajar jam pelajaran pertama. Kegiatan ini menandakan bahwa seorang siswa harus taat, tunduk, dan patuh kepada gurunya. Selain itu, setiap siswa harus menghormati dan menghargai guru-gurunya. Demikian pula dalam Islam yang sangat memerhatikan Ibtiram (rasa hormat) seorang murid kepada mursyidnya. Dengan demikian, tentunya keberkahan dari ilmu yang diajarkan guru tersebut dapat diterima oleh para siswanya dan menjadi 
ilmu yang bermanfaat, baik di dunia maupun di akhirat.

\section{KESIMPULAN}

Dari hasil pembahasan di atas, peneliti memperoleh hasil temuan sebagai berikut; Pertama, penanaman nilai-nilai Islam di SMP PGII 1 Bandung tersebut telah dilaksanakan dan diterapkan melalui kegiatan sebelum belajar yang meliputi kedisiplinan, membaca asmaul husna, membaca al-Qur'an dan doa setelahnya, menyanyikan lagu Indonesia Raya, membacakan kisah-kisah atau hadits, membaca buku, dan mengucapkan salam kepada guru.

Kedua, kegiatan tersebut diaplikasikan dalam kegiatan yang dilakukan sebelum belajar dengan dibimbing oleh guru sebagai central figur sehingga para siswa dapat mengikutinya dengan baik.

\section{DAFTAR PUSTAKA}

Alam, Lukis. (2016). Internalisasi Nilai-nilai Pendidikan Islam dalam Perguruan Tinggi Umum Melalui Lembaga Dakwah Kampus. ISTAW A: Jurnal Pendidikan Islam, Vol. 01 Nomor 02, Januari-Juni 2016

Fathoni, Muhammad Kholid. (2005). Pendidikan Islam dan Pendidikan Nasional (Paradigma Baru). Jakarta: Direktorat Jenderal Kelembagaan Agama Islam-Departemen Agama.

Light, D., Keller, S., \& Calhoun, C. (1989). Sociology. New York: Alfred A. Knopf.

Ma'arif, Samsul. (2014). Implementasi Nilainilai Pendidikan Islam dalam Menyambut Era Globalisasi. Jurnal Review Pendidikan Islam. 01(01) Juni 2014.

Moleong, Lexy J. (2011). Metodologi Penelitian kualitatif. Bandung: Remaja Rosdakarya.
Muhaimin. et. Al. (2004). Paradigma Pendidikan Islam, Upaya Mengefektifkan Pendidikan Agama Islam di Sekolah. Bandung: Remaja Rosdakarya

Muhtadi, Ali. (2006). Penanaman Nilai-nilai Agama dalam Pembentukan Sikap dan Perilaku Siswa Sekolah Dasar Islam Terpadu Luqman Al-Hakim Yogyakarta. Jurnal Penelitian dan Evaluasi Pendidikan. 07(01)

Pratiwi, Yana Dian Ikka. (2015). Penanaman Nilai-nilai Keagamaan dalam Meningkatkan Prestasi Belajar PAI Siswa (Studi Multisitus pada MTsN Tunggangri dan MTs $N$ Tulungagung. IAIN Tulungagung: Tesis

Suardi, M. (2015). Belajar dan Pembelajaran. Yogyakarta: Deepublish.

Zuhairini dan Abdul Ghafir. (2004). Metodologi Pendidikan Agama Islam. Malang: UM Press. 